\title{
Distribution of Xylella fastidiosa in Oaks in Florida and Its Association with Growth Decline in Quercus laevis
}

\author{
E. L. Barnard, Forest Pathologist, and E. C. Ash, Forest Biologist, Florida Division of Forestry, Forest Health \\ Section, Gainesville 32614-7100; D. L. Hopkins, Professor of Plant Pathology, University of Florida, Central \\ Florida REC, Leesburg 34748-8232; and R. J. McGovern, Associate Professor of Plant Pathology, University of \\ Florida, Gulf Coast REC, Bradenton 34203-9324
}

\begin{abstract}
Barnard, E. L., Ash, E. C., Hopkins, D. L., and McGovern, R. J. 1998. Distribution of Xylella fastidiosa in oaks in Florida and its association with growth decline in Quercus laevis. Plant Dis. 82:569-572.

A survey of more than 200 trees has documented the widespread occurrence of Xylella fastidiosa in Florida oak populations. The pathogen was detected readily via enzyme-linked immunosorbent assay in oaks exhibiting decline or leaf scorch symptoms and was infrequently detected in asymptomatic trees. It was also associated with reduced growth in Quercus laevis as measured by current-year shoot length. The occurrence of X. fastidiosa in $Q$. laevis and the evidence for its occurrence in $Q$. incana represent first reports for these oak hosts. The role of $X$. fastidiosa in oak decline scenarios deserves further attention.
\end{abstract}

Additional keywords: leaf scorch, oak decline, Quercus spp.

The fastidious xylem-inhabiting bacterium, Xylella fastidiosa Wells et al. (24), is associated with and in many cases causes leaf scorch and decline diseases in a variety of plant species $(11,12,17,24)$. Many leaf scorch disorders in broad-leaved tree species are associated with or attributed to $X$. fastidiosa, and the organism is widespread in tree populations (1-13,1517,19,20,24). X. fastidiosa has been known to occur in trees in Florida for years $(3,11,12)$, and has recently been reported in association with decline in live oak (Quercus virginiana Mill.) in southwest Florida (15). In 1992 and 1993, we evaluated more than 200 oaks throughout Florida for the presence of $X$. fastidiosa. Our objectives were (i) to determine the distribution of the pathogen in the state's oak populations, and (ii) to ascertain whether the bacterium was present (and common) in apparently healthy oaks as well as in oaks exhibiting leaf scorch, decline symptoms, or both.

Corresponding Author: Ed Barnard E-mail: fhealth@doacs.state.fl.us

Contribution No. 717, Bureau of Entomology, Nematology, Plant Pathology-Pathology Section.

Accepted for publication 9 February 1998.

Publication no. D-1998-0313-02R

This article is in the public domain and not copyrightable. It may be freely reprinted with customary crediting of the source. The American Phytopathological Society, 1998.

\section{MATERIALS AND METHODS}

Sample tree identification. In August 1992, County Foresters with the Florida Division of Forestry were asked to locate individual oaks representative of locally prevalent species in natural or urbanized environs which exhibited decline symptoms, including 25 to $30 \%$ crown dieback, premature leaf abscission, small, sparse, chlorotic foliage, definitive leaf scorch, or a combination of symptoms. At the same time, they were asked to locate nearby apparently healthy, asymptomatic individuals of the same species to be included in sample pairs. These sample pairs were visited in October to December 1992, and if suitable (free from obvious insect, disease or mechanical injury, site disturbance, chemical influences, etc.) were sampled for detection of $X$. fastidiosa. Twenty of the trees sampled in 1992 were sampled again in the fall of 1993.

Sampling and processing for detection of $X$. fastidiosa. Four to six small branchlets, approximately 0.25 to $0.75 \mathrm{~cm}$ in diameter, with several buds and attached leaves, were removed from the crowns of sample trees with a pole pruner. Leaves on sample branchlets from apparently healthy trees exhibited no symptoms of disease. Those on sample branchlets from declining or leaf-scorched trees may or may not have exhibited symptoms, depending upon the locus of individual sample branchlets within the crowns of symptomatic trees. In most cases, branchlets with symptomatic leaves were selected. Sample branchlets were placed in labeled plastic bags and transported in an ice chest to the Florida Division of
Plant Industry's Plant Pathology Laboratory in Gainesville.

In the laboratory, several $1.0-$ to $1.5-\mathrm{cm}$ segments of twig tips with terminal bud clusters were cut from sample branchlets. Subsamples of these twig tips were combined with short segments of leaf petioles or midribs from the leaves of the same tree to provide a composite tissue sample of approximately 1.0 to $1.5 \mathrm{~g}$ (fresh weight). Composite tissue samples were then squeezed in a Model 1 Leaf Squeezer (Ravenel Specialties Co., Seneca, SC), diluted 1:10 wt/vol in extraction buffer (20), and subjected to double-antibody sandwich (DAS) enzyme-linked immunosorbent assay (ELISA) with commercial polyclonal antisera (Agdia, Inc., Elkhart, IN) using peroxidase-labeled conjugate. Positive and negative controls were included with each lot of samples processed. Samples were considered positive for $X$. fastidiosa when they produced a visually intense yellow reaction as compared to negative controls, and when absorbance measured at $490 \mathrm{~nm}$ with an Emax precision microplate reader (Molecular Devices Corp., Sunnyvale, CA) exceeded $2.5 \times$ that of the negative controls. Following processing at the Plant Pathology Laboratory, residual sample branchlets and leaves from approximately $25 \%$ of our sample trees were immediately forwarded to the University of Florida's Central Florida Research and Education Center in Leesburg for verification. There, these samples were again processed via ELISA (above) and isolations for $X$. fastidiosa were attempted on periwinkle wilt medium (6).

Assessing growth decline in Quercus laevis. Because early field observations suggested a pronounced reduction in current-year (1992) shoot elongation in turkey oaks ( $Q$. laevis Walt.) exhibiting symptoms of decline or abundant leaf scorch, measurements were made to verify this phenomenon. Four branches were removed from random locations within the crowns of 16 apparently healthy trees and 16 trees exhibiting definitive leaf scorch. Sample tree pairs were distributed among four counties (Clay, Madison, Suwannee, and Citrus) in northern Florida. In the laboratory, current-year growth on each of the first 10 shoots on each branch, beginning with the terminal shoot and proceeding in a basipetal direction, was measured to the 
nearest $0.5 \mathrm{~cm}$. Differences between mean shoot lengths for symptomatic versus asymptomatic and paired Xylella-positive versus Xylella-negative trees were evaluated for significance at $P=0.05$ and $P=$ 0.01 using standard two-tailed $t$ tests (22).

\section{RESULTS}

A total of 206 oaks were sampled and processed in 1992. Species represented in the sample included turkey oak, southern red oak (Q. falcata Michx.), live oak, laurel oak ( $Q$. laurifolia Michx.), water oak (Q. nigra L.), post oak (Q. stellata Wangenh.), bluejack oak ( $Q$. incana Bartr.), and swamp chestnut oak ( $Q$. michauxii Nutt.; Table 1). Four species (Q. laevis, $Q$. falcata, $Q$. virginiana, and $Q$. laurifolia) were sampled extensively whereas four others (Q. nigra, Q. stellata, $Q$. incana, and $Q$. michauxii) were sampled infrequently, due primarily to their relative scarcity in the landscape and the relative lack of decline or leaf scorch symptoms occurring on them. Overall, very few healthy, asymptomatic oaks gave positive ELISA responses for $X$. fastidiosa. In contrast, high percentages of oaks with decline, leaf scorch symptoms, or both reacted positively for the pathogen. This association was particularly evident in $Q$. laevis and $Q$. falcata, but less so in $Q$. virginiana and $Q$. laurifolia (Table 1).

Verification processing of residual sample materials at the University of Florida's Central Florida Research and Education facility showed an excellent correspondence to results obtained via ELISA at the Plant Pathology Laboratory. Repeat ELISA results were nearly a $1: 1$ match with preliminary ELISA readings, and $X$. fastidiosa was isolated from nearly half of the samples (predominantly turkey oak) yielding a positive reaction for the pathogen via ELISA (data not shown).

Shoot measurements on $Q$. laevis revealed significant differences in currentyear (1992) shoot growth between leafscorched trees and asymptomatic trees, as well as between paired Xylella-positive and Xylella-negative trees. Current-year shoots on trees with leaf scorch symptoms were approximately $29 \%$ shorter than those on asymptomatic trees, and shoots on Xylellapositive trees were approximately $38 \%$ shorter than those on paired Xylella-negative trees (Fig. 1).

Eighteen turkey oaks and 2 bluejack oaks from the 1992 sample were sampled again in 1993 (Table 2). Of the 20 oaks sampled in 1993, 15 showed no change from their 1992 condition with respect to the presence of $X$. fastidiosa. Four oaks, however, showed a change from Xylellafree to Xylella-positive over the course of the year. Only 1 oak reflected a change from Xylella-positive to Xylella-negative (Table 2).

Figure 2 displays the geographical distribution of oaks sampled in Florida and the known distribution of $X$. fastidiosa within the state's oak populations.

\section{DISCUSSION}

In our ELISA analyses, we deliberately took a conservative approach toward identifying Xylella-infected trees. Accordingly, only those samples that gave clear and strong positive reactions were counted as Xylella-positive. This approach strengthens confidence in our positive data, but in actuality may have contributed to an overall underestimate of the pathogen's occurrence and distribution. Such an approach may have also contributed to the very limited number of Xylella-positives we recorded for symptomatic $Q$. virginiana and $Q$. laurifolia. These species are known hosts of $X$. fastidiosa and symptoms are often coincident with, if not indicative of, the presence of the organism $(12,15)$. Several samples from symptomatic and asymptomatic individuals of these two species (especially $Q$. virginiana) gave variable but unconvincing "positive" reactions; if we erred in our calls, we erred on the side of conservatism.

Many investigators have reported the occurrence of $X$. fastidiosa in symptomatic oaks only $(4,7,8,15)$. Others have noted the failure to detect the pathogen or its anti-

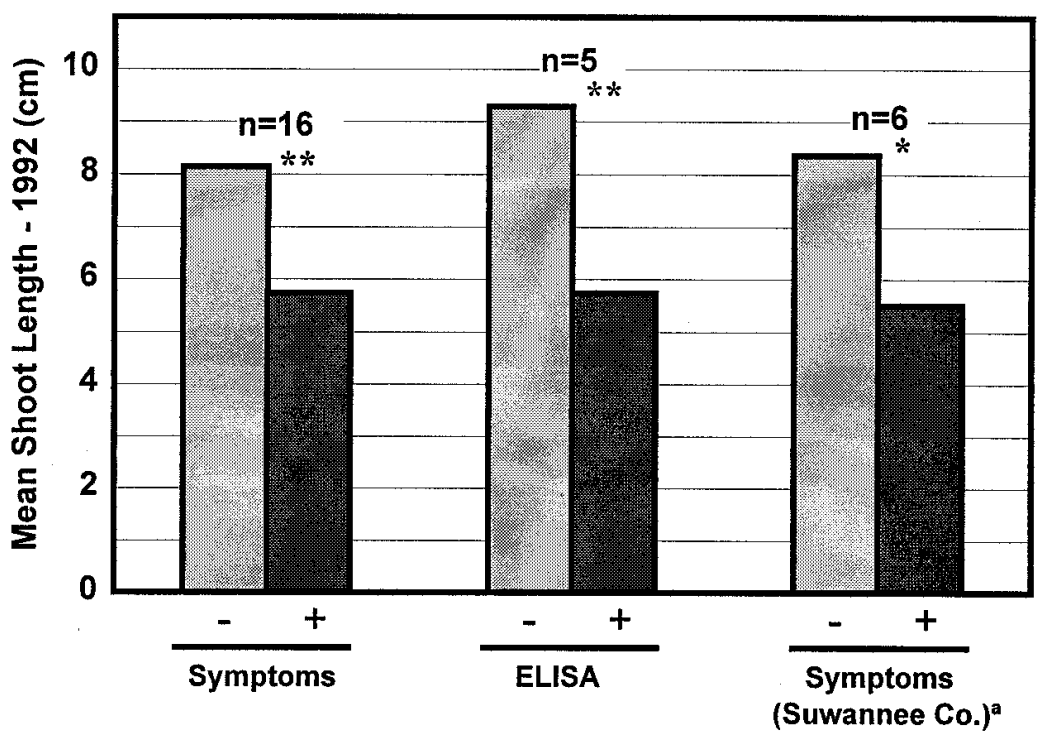

a One asymptomatic tree tested ELISA-positive, one symptomatic tree tested ELISA-negative

Fig. 1. Current-year (1992) shoot growth of Quercus laevis with and without definitive leaf scorch symptoms and positive enzyme-linked immunosorbent assay reactions for Xylella fastidiosa. Column pairs annotated with double or single asterisks indicate significant differences at $P=0.01$ and 0.05 , respectively.

Table 1. Oaks sampled in Florida during 1992 and results of enzyme-linked immunosorbent assay (ELISA) screening for Xylella fastidiosa

\begin{tabular}{|c|c|c|c|c|c|c|}
\hline \multirow[b]{2}{*}{ Species } & \multicolumn{3}{|c|}{ No. trees sampled by crown condition } & \multicolumn{3}{|c|}{ \% trees ELISA-positive } \\
\hline & Healthy $^{\mathbf{a}}$ & Symptomatic $^{\mathbf{b}}$ & With leaf scorch & Healthy $^{\mathrm{a}}$ & Symptomatic $^{\mathrm{b}}$ & With leaf scorch \\
\hline Quercus laevis & 42 & 46 & 42 & 2 & 65 & 60 \\
\hline Q. falcata & 9 & 11 & 8 & 0 & 46 & 63 \\
\hline Q. virginiana & 24 & 22 & 1 & 0 & 9 & 0 \\
\hline Q. laurifolia & 16 & 19 & 2 & 0 & 5 & 0 \\
\hline Q. nigra & 2 & 4 & 0 & 50 & 50 & $\ldots$ \\
\hline Q. stellata & 1 & 6 & 4 & 0 & 0 & 0 \\
\hline Q. incana & 1 & 2 & 1 & 0 & 100 & 100 \\
\hline Q. michauxii & 0 & 1 & 1 & 0 & 0 & 0 \\
\hline Total: weighted $\bar{x}$ & 95 & 111 & 59 & 2 & 38 & 53 \\
\hline
\end{tabular}

a Apparently healthy; no visible crown or foliar symptoms.

b Including dieback, crown-thinning, defoliation, chlorosis, and leaf scorch. 
gen(s) in symptomless oaks $(5,9,20)$. In our investigation, we found evidence of the organism in both symptomatic and asymptomatic trees, albeit extremely limited in the latter (Table 1 and 2). Presumably, the sensitivity of the ELISA methodology, the large numbers of oaks we sampled, and the possibility of latent disease development could account for this presence in asymptomatic trees.

A seemingly disproportionate number of symptomatic or leaf-scorched survey trees from the southern half of peninsular Florida were Xylella-negative when subjected

Table 2. Tree crown conditions and associated enzyme-linked immunosorbent assay (ELISA) test results for Xylella fastidiosa in oaks sampled in 1992 and 1993

\begin{tabular}{|c|c|c|c|c|c|}
\hline \multirow[b]{2}{*}{ Species, location } & \multirow[b]{2}{*}{1992 tree no. } & \multicolumn{2}{|c|}{ Crown condition/symptoms ${ }^{\mathbf{a}}$} & \multicolumn{2}{|c|}{ ELISA response } \\
\hline & & 1992 & 1993 & 1992 & 1993 \\
\hline \multicolumn{6}{|l|}{$\overline{Q u e r c u s ~ l a e v i s ~}$} \\
\hline \multirow[t]{6}{*}{ Clay Co. } & 47 & LS & LS & + & + \\
\hline & 48 & $\mathrm{H}$ & $\mathrm{H}$ & - & + \\
\hline & 49 & LS & LS & + & + \\
\hline & 50 & $\mathrm{H}$ & $\mathrm{H}$ & - & + \\
\hline & 51 & $\mathrm{H}$ & $\mathrm{H}$ & - & - \\
\hline & 52 & LS & LS & + & + \\
\hline \multirow{4}{*}{ Suwannee Co. } & 53 & $\mathrm{H}$ & $\mathrm{H}$ & - & - \\
\hline & 54 & LS,CT & LS,CT,DB & + & + \\
\hline & 55 & LS & LS & + & + \\
\hline & 56 & $\mathrm{H}$ & $\mathrm{H}$ & - & + \\
\hline \multirow[t]{2}{*}{ Madison Co. } & 61 & $\mathrm{H}$ & $\mathrm{H}$ & - & - \\
\hline & 62 & LS & LS & + & + \\
\hline \multirow[t]{6}{*}{ Citrus Co. } & 63 & LS,DEF,DB & LS & + & - \\
\hline & 64 & $\mathrm{H}$ & $\mathrm{H}$ & - & - \\
\hline & 65 & $\mathrm{H}$ & $\mathrm{H}$ & - & - \\
\hline & 66 & LS,DB & LS,CT,DB & + & + \\
\hline & 67 & LS & LS & + & + \\
\hline & 68 & $\mathrm{H}$ & LS & - & + \\
\hline \multicolumn{6}{|l|}{ Q. incana } \\
\hline \multirow[t]{2}{*}{ Madison Co. } & 57 & LS,CT & LS,CT,DEF,DB & + & + \\
\hline & 58 & $\mathrm{H}$ & $\mathrm{H}$ & - & - \\
\hline
\end{tabular}

a Visual assessment of crown/foliage symptoms: $\mathrm{H}=$ healthy, $\mathrm{LS}=$ leaf scorch, $\mathrm{CT}=$ crown thinning, $\mathrm{DEF}=$ defoliating, $\mathrm{DB}=$ dieback .

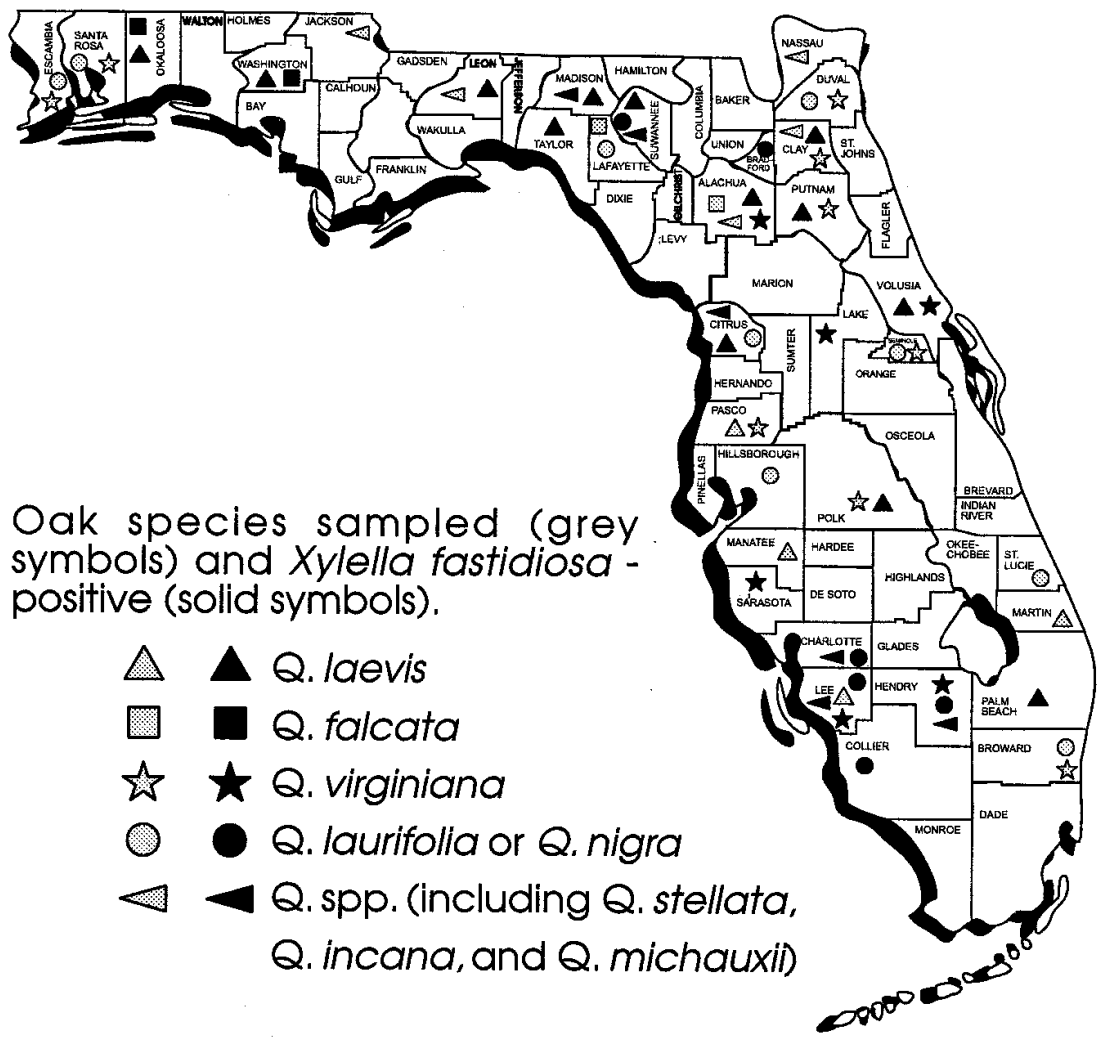

Fig. 2. Distribution of Quercus spp. sampled for Xylella fastidiosa in Florida and known distribution of the pathogen in the state's oak populations. Map reflects survey data and incidental data accumulated by authors over time. to ELISA. Based on the apparently strong association between $X$. fastidiosa and decline or leaf scorch symptoms (Table 1 and 2 ), this was unexpected. While several explanations could be posited for this phenomenon (e.g., processing error, absence of pathogen), we suspect season or timing of sampling could be a factor. McGovern and Hopkins (15) have reported $X$. fastidiosa from symptomatic oaks at these latitudes (data reflected in southwest Florida; Fig. 2). They sampled primarily in early October, whereas most of our south-Florida samples were collected later in the year. However, as in the survey reported here, McGovern and Hopkins (unpublished results) also failed to confirm $X$. fastidiosa in symptomatic oaks in Broward County in southeastern peninsular Florida.

Overall, results of our survey provide evidence that $X$. fastidios $a$ is widespread in Florida oak populations, strongly associated with leaf scorch symptoms, and apparently related to, if not a cause of, growth decline in $Q$. laevis. These results support and expand the more limited reports of Hopkins and Alderz (12) and McGovern and Hopkins (15). In addition, this paper provides the first report of occurrence of this pathogen in $Q$. laevis and preliminary evidence of its occurrence in $Q$. incana (not verified in this species by isolation or direct observation).

The prevalence of $X$. fastidiosa in oaks in Florida in both natural and urbanized environs, especially in the very abundant $Q$. laevis, suggests that host oak species may represent a significant inoculum reservoir for the pathogen. Further, the coincidence of Xylella-associated leaf scorch, oak decline, and their overlapping symptomatologies in Florida and the southern United States $(4,8,9,12,14,21,23)$ raises legitimate questions regarding the possible role or roles of $X$. fastidiosa in regionwide oak decline. Also, in Florida at least, growth decline and $X$. fastidiosa in $Q$. laevis should be evaluated in relationship to root rot caused by Armillaria tabescens (Scop.) Dennis, Orton \& Hora, a common disease of this oak species (Barnard, unpublished results; 18).

\section{ACKNOWLEDGMENTS}

We thank the many Division of Forestry personnel who contributed to the oak location and sampling processes, and L. Breman for technical assistance with respect to the ELISA procedures.

\section{LITERATURE CITED}

1. Aldrich, J. H., Gould, A. B., and Martin, F. G. 1992. Distribution of Xylella fastidiosa within roots of peach. Plant Dis. 76:885-888

2. Anonymous. 1993. Bacterial leaf scorch of landscape trees. Cent. Urban Ecol. Inf. Bull. National Park Service. Washington, DC.

3. Barnard, E. L. 1985. Sycamore Leaf Scorch. Division of Plant Industry. Fla. Dep. Agric. Consumer Serv. Plant Pathol. Circ. No. 276.

4. Blake, J. H. 1993. Distribution of Xylella fastidiosa in oak, maple, and sycamore in South Carolina. Plant Dis. 77:1262.

5. Chang, C. J., and Walker, J. T. 1988. Bacterial 
leaf scorch of northern red oak: Isolation, cultivation, and pathogenicity of a xylemlimited bacterium. Plant Dis. 72:730-733.

6. Davis, M. J., French, W. J., and Schaad, N. W. 1981. Axenic culture of the bacteria associated with phony disease of peach and plum leaf scald. Curr. Microbiol. 6:309-314.

7. Gould, A. B., Wells, J. M., and Clarke, B. B. 1992. Distribution of oak leaf scorch in the Delaware Valley, New Jersey. (Abstr.) Phytopathology 82:1160.

8. Hartman, J. R., Eshenaur, B. C., and Jarflors, V. E. 1995. Bacterial leaf scorch caused by Xylella fastidiosa: a Kentucky survey; a unique pathogen; and pin oak, a new host. J. Arboric. 21:77-82.

9. Haygood, R. A. 1988. Fastidious, xyleminhabiting bacteria associated with scorch in pin oak and southern red oak trees in the Carolinas. (Abstr.) Phytopathology 78:628.

10. Hearon, S. S., Sherald, J. L., and Kostka, S. J. 1980. Association of xylem-limited bacteria with elm, sycamore, and oak leaf scorch. Can. J. Bot. 58:1986-1993.

11. Hopkins, D. L. 1989. Xylella fastidiosa: xylem-limited bacterial pathogen of plants.
Annu. Rev. Phytopathol. 27:271-290.

12. Hopkins, D. L., and Alderz, W. C. 1988. Natural hosts of Xylella fastidiosa in Florida. Plant Dis. 72:429-431.

13. Kostka, S. J., Tattar, T. A., and Sherald, J. L. 1986. Elm leaf scorch: abnormal physiology in American elms infected with fastidious, xylem-inhabiting bacteria. Can. J. For. Res. 16:1088-1091.

14. McCracken, F. I. 1985. Oak decline and mortality in the south. Pages 77-81 in: Proc. Third Symp. Southeastern Hardwoods, Dothan, AL. South. Reg. U. S. Dep. Agric. For. Serv.

15. McGovern, R. J., and Hopkins, D. L. 1994 Association of Xylella fastidiosa with leaf scorch and decline of live oak in Florida. Plant Dis. 78:924.

16. Mizubuti, E. S. G., Matsuoka, K., and Parizzi, P. 1994. Association of Xylella-like bacteria with sweet orange with variegated chlorosis symptoms in the Zona da Mata region of Minas Gerais. Fitopatol. Bras. 19:241-244.

17. Raju, B. C., and Wells, J. M. 1986. Diseases caused by fastidious xylem-limited bacteria and strategies for management. Plant Dis. 70:182-186.

18. Rhoads, A. S. 1950. Clitocybe root rot of woody plants in the southeastern United States. U. S. Dep. Agric. Circ. No. 853.

19. Sherald, J. L., and Kostka, S. J. 1992. Bacterial leaf scorch of landscape trees. J. Arboric. 18:57-63.

20. Sherald, J. L., and Lei, J. D. 1991. Evaluation of a rapid ELISA test kit for detection of $X y$ lella fastidiosa in landscape trees. Plant Dis. 75:200-203.

21. Sherald, J. L., Patton, E. N., Stidham, T. M. and Favre, C. L. 1994. Incidence and development of bacterial leaf scorch of elm on the National Mall. J. Arboric. 20:18-23.

22. Snedecor, G. W., and Cochran, W. G. 1967 Statistical Methods, 6th ed. Iowa State Univ. Press, Ames

23. Starkey, D. A., Oak, S. W., Ryan, G. W., Tainter, F. H., Redmond, C., and Brown, H. D. 1989. Evaluation of oak decline areas in the South. U. S. Dep. Agric. For. Serv. Prot. Rep. R8-PR-17.

24. Wells, J. M., Raju, B. C., Hung, H. Y., Wiesburg, W. G., Mandelco-Paul, L., and Brenner, D. J. 1987. Xylella fastidiosa gen. nov., sp. nov.: Gram-negative, xylem-limited, fastidious plant bacteria related to Xanthomonas spp. Int. J. Syst. Bacteriol. 37:136-143. 